\title{
Yönetim Kurulundaki Yabancı Üye Sayısının ve Yabancı Sahipliğinin Finansal Performans Üzerindeki Etkisi
}

\author{
The Impact of Foreign Directors and Foreign Ownership on Financial Performance
}

\author{
Mesut DOĞAN' 1 , Yusuf TOPAL ${ }^{2}$
}

\begin{abstract}
ÖZET
Bu çalışmanın amacı yönetim kurulundaki yabancı üye sayısının ve yabancı sahipliğinin finansal performans üzerindeki etkisini tespit etmektir. Bu amaç doğrultusunda araştırmada 2002-2012 yıllarına ait Borsa İstanbul (BIST) imalat sanayide faaliyet gösteren 136 firmanın verilerinden yararlanılmıştır. Araştırmada bağımlı değişken olarak muhasebe ve piyasa esaslı finansal performans göstergeleri kullanılmıştır. Araştırmada Stata 13.0 programı yardımı ile Beck-Katz (1995) tarafından geliştirilen dirençli tahminci tercih edilmiştir. Yapılan analizler sonucunda yönetim kurulundaki yabancı üye sayısının ve yabancı sahiplik seviyesinin artması, firmanın piyasa değerini olumlu bir şekilde etkilediği tespit edilmiştir. Bu sonuçlar kaynak bağımlılığı ve vekâlet teorisini destekler niteliktedir.
\end{abstract}

Anahtar Kelimeler: Yönetim Kurulundaki Yabancı Üye, Yabancı Sahiplik, Finansal Performans

\section{GiRiş}

Günümüzde işletmelerin ayakta kalabilmesi ve rekabet edebilmesi için ulusal bazda pazarda lider olması yetmemekte, çok boyutlu düşünmeleri gerekmektedir. Bu doğrultuda işletmeler, doğru kararlar verebilmek ve dış pazarlara daha risksiz açılabilmek için ilgili pazarı çok iyi tanıyan diğer işletmeler ile şirket birleşmeleri şeklinde işbirliklerine gitmektedirler. Türkiye'de ise son yıllarda Borsa İstanbul (BIST)'a kote şirketlerinin hisseleri yabancı yatırımcılar tarafından satın alınmakta ve uluslararası pazarlarda işbirliği yapmaktadırlar. Söz konusu birleşmeler veya satın almalar neticesinde yabancı yatırımcı sahipliği ve yabancı yöneticilerin sayısı ülkemizde artmaya başlamıştır.

Yabancı yatırımcılar, değişik ülkelerde uzun vadeli yatırım yapabilmek için güven unsuruna önem vermekte yatırım yapmadan önce haklarının sınırlarını

\begin{abstract}
The purpose of this study is to analyze the impact of foreign directors and foreign ownership on financial performances of companies traded in Borsa Istanbul (BIST). The study made use of data of 136 firms continuously active in BIST manufacturing industry between 2002 and 2012. Accounting-based and market-based performance indicators have been taken into account as performance criteria. Robust estimator which was developed by BeckKatz (1995) was preferred for the study along with Stata 13.0 software. Results of the analyses suggested that foreign directors and foreign ownership, had impact on market value of companies. The findings of the study are parallel with the agency theory and resource dependence theory.
\end{abstract}

Keywords: Foreign Directors, Foreign Ownership, Financial Performance

bilmek istemektedir. Dolayısıyla firmalar, uzun vadeli ve yatırımının karşılığını almak konusunda sabırlı olan sermayeyi kendilerine çekebilmek için güvenilir ve genel kabul görmüş kurumsal yönetim düzenlemeleri yapmak durumundadırlar. Bu yüzden yabancı yatırımcının ilgisini çekebilmek için aranan güven, başarılı kurumsal yönetim sistemi oluşturulmasına ve oluşturulan kurumsal yönetim sisteminin korunmasına yönelik temel prensiplerin belirlendiği uluslararası bir anlaşma ile sağlanabilir (Karabıyık, 2011: 47) . Bununla birlikte La Porta, Lopez-DeSilanes ve Shleifer (1999)'in de belirttiği gibi yabancı yatırımcılar kurumsal yönetim mekanizmalarının yetersiz olduğu gelişmekte olan ülkelere hâkim ortak olma yolunu tercih ederek hukuksal boşluğu doldurmaktadır.

Kurumsal yönetim, ortaklarca işletme yöneticilerinin kullanımına verilen varlıklar ve değerlerin verimli sonuç verecek biçimde 
kullanılmasını ve yöneticilerin bu kullanım biçimi ile alınan sonuçlar hakkında ortaklara hesap verecek durumda bulunmalarını amaçlayan bir sistemler topluluğudur. Bu özelliğiyle kurumsal yönetim, dar anlamda bir işletmenin, ortaklarılya ilişkilerini düzenleyen sistemler topluğu, geniş anlamda da işletme ile toplumun ilişkilerini düzenleyen sistemler topluluğu biçiminde ifade edilebilir (Aysan, 2007: 18). $\mathrm{Bu}$ bağlamda kurumsal yönetim uygulamalarının faydalarından birisi yabancı yatırımcıların güvenini tesis edilerek, uzun vadeli sermaye girişini hızlandırmasıdır. Başka bir ifade ile iyi bir kurumsal işletme yönetimi, yatırımcının güvenini sağlamak bakımından gerekli olduğu kadar, özellikle gelişmekte olan ülkelerde, direkt yabancı yatırımları çekebilmek bakımından da önemli bir araç niteliğindedir. Aktif yatırımcıların gözünde işletmenin çekiciliği, eğer işletme kendilerinin kurumsal yönetim ilkelerine uyuyorsa artacaktır (Kargın, 2006).

Konu ile ilgili teorik tartışmalar incelendiğinde iki teori ön plana çıkmaktadır. Bunlar: Kaynak Bağımlılığı Teorisi (Resource Dependence Theory) ve Vekalet Teorisi'dir. Kaynak bağımlılığı teorisine göre; yönetim kuruluna bağımsız ve bağımlı üyelerin getirilmesi bağlantıların kurulması, bilginin iletimi, değişik konularda destek almayı sağlayan kaynakların temin edilmesi için faydalı olacaktır. Yönetim kurulunda (YK) etnik köken, kültürel altyapı bakımında çeşitliliğin arttırılması, yönetim kurulunun bağımsızlığını arttıracaktır. Başka bir ifade ile yönetim kurulunda çeşitliliğin arttırılması, işletmenin kaynaklardaki çeşitliliğini arttırmasını sağlayacak böylelikle işletme performansını olumlu yönde etkilenecektir. Vekalet teorisine göre ise; yönetim kurulunda bağımsız olmayan üyeler ile bağımsız üyeler arasında bir dengenin olması gerekmektedir. Bu denge içinde bulunan bağımsız yönetim kurulu üyeler üst düzey yönetimi daha etkili bir şekilde kontrol edip gözetleyecektir (Ocak, 2013: 109). Özetle vekâlet teorisine göre; yönetim kurulunda, etnik köken açısından çeşitliliğin olması halinde yönetim kurulunun bağımsızlığını arttıracak ve böylelikle işletme performansı olumlu yönde etkilenecektir.

Yönetim kurulundaki yabancı üye (YKYU) sayısı ve yabancı sahiplik (YABPAYI) ile finansal performans arasındaki ilişkiyi inceleyen çalışmalar incelendiğinde karma sonuçların tespit edildiği görülmüştür. $Y K Y U$ sayısı ile finansal performans arasında Oxelheim ve Randøy (2003); Kondrunina (2013) pozitif bir ilişki, buna karşın Masulis, Wang ve Xie (2012); Cavaco vd. (2013) negatif bir ilişki tespit etmişlerdir. Bu çalışmaların dışında Randøy, Thomsen ve Oxelheim (2006); Shukeri, Shin ve Shaari (2012) gibi yazarlar ise $Y K Y U$ sayısı ile firma performansı arasında anlamlı olmayan bir ilişki elde etmişlerdir. Yabancı sahiplik yüzdesinin artması halinde Lee (2009); Elsayed (2011); Abbasi, Kalantari ve Abbasi (2012) gibi yazarlar firmanın hem piyasa hem de muhasebe esaslı performans göstergelerinin de artacağını savunmuşlardır. Choi, Park ve Yoo (2007); Cornett vd. (2007); Cho ve Kim (2007) yabancı yatırımcı sahipliği ile karlılık göstergeleri arasında pozitif; buna karşın Sueyoshi, Goto ve Omi (2010); Wellalage ve Locke (2012); Moscu (2013) ise negatif bir ilişki tespit etmişlerdir. Bu çalışmaların dışında Barnhart ve Rosenstein (1998); Zeitun ve Tian (2007); Mollah, Al Farooque ve Karim (2012) gibi yazarlar ise yabancı yatırımcı sahiplik düzeyinin firma performansı üzerinde etkili olmadığını ifade etmişlerdir. Tüm bu sonuçlar konuya olan ilgiyi artırmıştır.

Konuya ilişkin ulusal literatür taramasında yönetim kurulundaki yabancı üye sayısı ve yabancı sahipliği ile ilgili bir çalışmaya rastlanılmamıştır. Uluslararası literatürde ise yönetim kurulundaki yabancı üye sayısının ve yabancı sahipliğinin finansal performans üzerindeki etkisine yönelik araştırma sayısı son derece azdır. Bu araştırma geniş veri setiyle ulusal ve uluslararası literatüre katkı sağlayacaktır. Bu yüzden çalışma oldukça önemlidir.

$\mathrm{Bu}$ çalışmanın amacı yönetim kurulundaki yabancı üye sayısının ve yabancı sahipliğinin finansal performans üzerindeki etkisini incelemektir. Bu amaç doğrultusunda araştırmada 2002-2012 yıllarına ait BIST imalat sanayide faaliyet gösteren 136 firmanın verilerinden yararlanılmıştır. Araştırmada 4 adet bağımlı değişken kullanılmıştır. Bunlardan birincisi muhasebe esaslı finansal performans göstergeleri olan Varlık Karlılığı (ROA) ve Öz sermaye karlılığı (ROE)'dir. İkincisi ise piyasa esaslı göstergelerden biri olan Tobin's q performans ölçütüdür. Son performans göstergesi olan ve son yıllarda yapılmış olan akademik çalışmalarda kullanılan Z Altman Skoru'dur. Sonuç olarak bu araştırmada bağımlı değişken olarak hem muhasebe ve piyasa esaslı finansal performans göstergeleri hem de Z Altman skoru kullanılmıştır.

Araştırma dört bölümden oluşmaktadır. Birinci bölümde YKYU sayısı ve yabancı sahipliği ile finansal performans arasındaki ilişkiyi inceleyen araştırmalar özetlenmiştir. İlerleyen kısımda çalışmanın verileri 
tanıtılarak hipotezler ve modeller geliştirilmiş ve sonuç kısmında genel bir değerlendirme yapılmıştır.

\section{LITERATÜR TARAMASI}

$\mathrm{Bu}$ bölümde YKYU sayısı ve yabancı sahipliği bağımsız değişkenleri ile finansal performans göstergeleri arasındaki ilişkiyi inceleyen çalışmalara değinilecektir. Başka bir ifade ile söz konusu bağımsız değişkenlerin muhasebe ve piyasa temelli performans göstergeleri üzerindeki etkisi test eden araştırmalar bu bölümde özetlenecektir.

\subsection{Yönetim Kurulundaki Yabancı Üye Sayısının İşletmenin Finansal Performansına Etkisi}

Kurumsal yönetim ile finansal performans arasındaki ilişkiyi test eden çalışmalarda son yıllarda yönetim kurulundaki yabancı üye sayısı bağımsız değişken olarak kullanılmaya başlanmıştır. YKYU sayısı ile finansal performans arasındaki ilişkiyi inceleyen çalışmalar incelendiğinde karma sonuçların tespit edildiği görülmüştür. Bu araştırmalar aşağıda özetlenecektir.

Randøy, Thomsen ve Oxelheim (2006) 161 İsviçre, 154 Danimarka ve 144 Norveç firmasının 2005 yılının verileri ile bir örneklem oluşturarak yönetim kurulu yapısının karlılık ve firma değerine etkisini incelemişlerdir. Geliştirilen regresyon modellerinin sonucunda YKYU oranının ROA ve firmaların piyasa değeri üzerinde anlamlı bir etkisini bulamamışlardır. Benzer bir şekilde Rose (2007) 1998-2001 yıllarını kapsayan analizinde Kopenhag Borsası'nda işlem gören şirketlerin yönetim kurulu yapısının performanslarını etkileyip etkilemediğini araştırmıştır. Yapılan analiz sonucunda kontrol değişkeni olarak modele dâhil ettiği YKYU oranı ile Tobin's q olarak ölçülen şirket performansı arasında önemli bir ilişki bulunamamıştır. Aynı yıl gerçekleştirilen başka bir araştırmada Choi, Park ve Yoo (2007) kurumsal yönetim reformlarını Kore firmaları açısından araştırmışlardır. Çalışma neticesinde YKYU sayısı ile Tobin's q arasında pozitif ancak anlamlı sonuçlar elde etmişlerdir.

Finans sektörü dışında Norveç ve İsveç'te faaliyette bulunan firmaların yönetim kurulundaki yabancı üye sayısının firma değeri üzerindeki etkisini Oxelheim ve Randøy (2003) en küçük kareler (EKK) ve iki aşamalı en küçük kareler (2EKK) yöntemleri yardımıyla test etmişlerdir. 650 gözlemden oluşan ve 1998-1996 yıllarını içine alan çalışma sonucunda YKYU sayısı ile firma değeri arasında pozitif ve anlamlı ilişkiler bulmuşlardır. Benzer bir şekilde Shukeri, Shin ve Shaari (2012) 10 farklı sektör ile 2011 yılına ait 300 firma verisi kullandıkları çalışmalarında yönetim kurulu özelliklerinin firma performansına etkisini araştırmışlardır. Regresyon modelinin sonucunda yönetim kurulunda yabancı üye bulunan firmaların finansal yönden daha başarılı olduklarını tespit etmişlerdir. Söz konusu bulguları yazarlar; konsensüs gerektiren grup problem çözme ve karar almada yabancı üyelerinin olumlu katkı yaptıkları şeklinde ve denetim fonksiyonunun daha işlevsel olması ile açıklamışlardır. Ujunwa (2012) Nijerya firmaları üzerine yaptığı çalışmada yönetim kurulu özelliklerinin finansal performans üzerindeki etkisini sabit etkiler ve rassal etkiler modeli yardımıyla ampirik olarak test etmiştir. 1991-2008 yılları arasında ve 122 firma verisinden yararlandıkları araştırma sonucunda YKYU sayısı ile firma performansı arasında pozitif bir ilişki ortaya koymuştur. Kondrunina (2013) Ukrayna'da faaliyette bulunan 94 firmanın YKYU sayısı ile firma performansı arasındaki ilişkiyi inceledikleri çalışma sonucunda YKYU sayısı ile ROA arasında pozitif bir ilişki elde etmiştir. Yazar bu bulguları; yönetim kurulunda etnik köken, kültürel altyapı bakımından çeşitliliğin arttırılması ile yönetim kurulunun bağımsızlığının da arttığını ve böylelikle firma performansına olumlu katkı yapmasıyla ilişkilendirmiştir.

Masulis, Wang ve Xie (2012) S\&P 1500 borsa endeksinde bulunan ortalama 1109 firma açısından yönetim kurulundaki yabancı üye sayısının firma performansı üzerindeki etkisini 1998-2006 yıllarının verilerinden yararlanarak incelemişlerdir. Modelin tahmin sonuçlarına göre; YKYU oranı ile Tobin's q arasında negatif ve anlamlı sonuçlar ortaya koymuşlardır.

Cavaco vd. (2013) çalışmalarında, kurumsal yönetim mekanizmalarının Fransız firmalarının operasyonel performansına etkisini ölçmeyi amaçlamışlardır. Analiz sonucunda YKYU oranı ile ROA ve ROE arasında negatif ilişkiler tespit etmişlerdir. Buna karşın; aynı yıl yapılan başka bir çalışmada Schwizer, Soana ve Cucinelli (2013) 2006-2008 yılları arasında İtalya Menkul Kıymetler Borsası'nda işlem gören 246 firma açısından yönetim kurulu yapısı ile firma performansı arasındaki ilişkiyi EKK yöntemi aracılığıyla incelemişlerdir. Gerçekleştirilen analiz sonucunda YKYU sayısı ile firma performansı arasında anlamlı ilişki belirlenememiştir. 
Özetle YKYU sayısının veya oranının firma performansı üzerindeki etkisini inceleyen çalışmaların az olduğu ve son yıllarda yapıldıkları görülmektedir. Yapılmış olan çalışmalarda farklı sonuçların tespit edilmesi yönetim kurulunda yabancı üye konusunda bir fikir birliği olmadığını göstermektedir. Bununla birlikte farklı ülkelerde yapılan çalışmalarda örneklemin değişmesi ile birlikte sonuçların da farklı bir şekilde tespit edilmesi olağan bir durum olarak ifade edilebilir.

Tablo 1: YKYU Sayısı İle Finansal Performans Arasındaki Illişkiyi İnceleyen Çalışmaların Özetlenmesi

\begin{tabular}{|c|c|c|c|c|c|c|c|}
\hline \multirow{2}{*}{ Yazar } & \multirow{2}{*}{ Yıl } & \multirow{2}{*}{ Ülke } & \multirow{2}{*}{ Dönem } & \multirow{2}{*}{ Firma Sayısı } & \multirow{2}{*}{ Model } & \multicolumn{2}{|c|}{ Performans Ölçümü } \\
\hline & & & & & & Tobin's q & Karlılık \\
\hline Oxelheim ve Randøy & 2003 & Norveç & 1996-1998 & 132 & EKK/2EKK & $+^{*}$ & \\
\hline Oxelheim ve Randøy & 2003 & İsveç & 1996-1998 & 121 & $\mathrm{EKK} / 2 \mathrm{EKK}$ & $+^{*}$ & \\
\hline Randøy vd. & 2006 & İsviçre & 2005 & 161 & EKK & - & - \\
\hline Randøy vd. & 2006 & Norveç & 2005 & 144 & EKK & - & - \\
\hline Randøy vd. & 2006 & Danimarka & 2005 & 154 & EKK & - & - \\
\hline Choi vd. & 2007 & Kore & $1999-2002$ & 450 & EKK/2EKK & + & \\
\hline Rose & 2007 & Danimarka & 1998-2001 & +100 & EKK & - & \\
\hline Ujunwa & 2012 & Nijerya & $1991-2008$ & 122 & SEM/REM & & $+^{*}$ \\
\hline Shukeri vd. & 2012 & Malezya & 2011 & 300 & EKK & & $+^{*}$ \\
\hline Masulis vd. & 2012 & $A B D$ & $1998-2006$ & $1109^{a}$ & EKK/2EKK/SEM & $-*$ & \\
\hline Cavaco vd. & 2013 & Fransa & $2003-2011$ & $237^{\mathrm{a}}$ & EKK/GLM & & $-* /-* /-/-$ \\
\hline Schwizer vd. & 2013 & İtalya & $2006-2008$ & 246 & EKK & + & \\
\hline Kondrunina & 2013 & Ukrayna & 2013 & 94 & EKK & & $+^{*}$ \\
\hline
\end{tabular}

*istatistiksel olarak anlamlı olduğunu göstermektedir.

allgili dönemler arasında ortalama firma sayısını göstermektedir.

EKK; en küçük kareler yöntemini, 2EKK; iki aşamalı en küçük kareler yöntemini, GLM; genelleştirilmiş doğrusal modelini, SEM; sabit etkiler modelini, REM; rassal etkiler modelini, göstermektedir.

\subsection{Yabancı Sahipliğinin İşletmenin Finansal Performansına Etkisi}

Kaynak bağımlılığı teorisine göre; işletmelerin sermaye intiyacını daha kolay elde edebilmeleri için yabancı yatırımcıların ülkeye teşvikinin artırılması gerekmektedir. Yabancı yatırımcı sahipliğinin finansal performans üzerindeki etkisi son yıllarda incelenmeye başlanmıştır. Konuya ilişkin literatür taramasında birkaç çalışma dışında yabancı yatırımcı sahipliği ile finansal performans arasında pozitif bir ilişki tespit edildiği görülmüştür. Söz konusu çalışmalar aşağıda özetlenmiştir.

Barnhart ve Rosenstein (1998) 1990 yılında S\&P 500 borsa endeksinde bulunan 321 Amerikan firması üzerine yaptıkları araştırmalarında yönetim kurulu (YK) yapısı ile piyasa performansı arasındaki ilişkiyi incelemişlerdir. Analiz sonuçlarında kurumsal holdinglerin sermaye payı ile Tobin's q arasında istatistiksel olarak anlamlı olmayan bir ilişki belirlemişlerdir. Finans sektörü dışında Norveç ve İsveç'te faaliyette bulunan firmaların YK yapısının firma değeri üzerindeki etkisini Oxelheim ve Randøy (2003); en küçük kareler (EKK) ve iki aşamalı en küçük kareler (2EKK) yöntemleri yardımıyla test etmişlerdir. 650 gözlemden oluşan ve 1998-1996 yıllarını içine alan çalışma sonucunda yabancı yatırımcıların sermaye payı ile firma değeri arasında pozitif ve anlamlı ilişkiler bulmuşlardır. Sonuç olarak yazarlar yabancıların sermaye payı arttıkça vekâlet maliyetlerinin azaldığını belirtmişlerdir.

Cornett vd. (2007) S\&P 100 borsa endeksinde bulunan firmalarda yönetim kurulu büyüklüğü ile performans arasındaki ilişkiyi EKK regresyon yöntemi aracılığıyla test etmişlerdir. 1993-2000 yıllarının verilerinden yararlandıkları çalışma sonucunda yabancı yatırımcı sahipliği ile ROA pozitif bir ilişki tespit etmişlerdir. 
1989-2002 yıllarının veri seti ile halka açık 59 Ürdün firması üzerinde ortaklık yapısının performans üzerindeki etkisini inceleyen Zeitun ve Tian (2007) yabancı yatırımcıların sermaye payı ile ROA ve ROE arasında anlamlı olmayan bir ilişki; buna karşın Tobin's q arasında negatif ve anlamlı bir ilişki gözlemlemişlerdir. Cho ve Kim (2007) çalışmalarında, ortaklık yapısının karlıık üzerindeki etkisini 1998 yılında Kore'de faaliyette bulunan 347 firma açısından incelemişlerdir. Geliştirilen modellerin bir kısmında yabancı yatırımcıların sermaye payı ile firma karlılığı (ROA) arasında pozitif \%1 düzeyinde anlamlı sonuçlar ortaya koymuşlardır.

Lee (2009) doktora tezinde Kore borsalarında 2000-2006 yıllarında işlem gören 579 firmada kurumsal yönetim ile performans arasındaki ilişkiyi araştırmıştır. Yapılan analiz sonucunda yabancı yatırımcı sahipliği ile Tobin's q ve ROA arasında pozitif ve istatistiksel olarak anlamlı ilişki belirlemiştir. Benzer şekilde Elsayed (2011) çalışmasında, Mısır Borsası'na kayıtlı 92 firmanın yönetim kurulu yapısı ve ortaklık yapısı ile performansı arasındaki ilişkiyi ölçmek istemiştir. Modelin tahmin sonuçlarına göre, kurumsal yatırımcı ve uluslararası yatıımcı sahipliği ile piyasa esaslı performans göstergesi olan Tobin's q arasında negatif bir ilişki; buna karşın muhasebe esaslı performans göstergesi olan ROA ve ROE arasında ise pozitif bir ilişki elde edilmiştir. Sueyoshi, Goto ve Omi (2010) ise 1999-2006 yılları arasında Japonya'da Tokyo Menkul Kıymetler Borsası'nda imalat sanayide işlem gören 270 firmada kurumsal yönetim ile performans arasındaki ilişkiyi incelemişlerdir. Gerçekleştirilen analiz sonucunda yabancı yatırımcı sahipliğinin artması firmaların operasyonel performansının da azalmasına neden olmaktadır.

Wellalage ve Locke (2012) ortaklık yapısı ile firma finansal performans arasındaki ilişkiyi panel veri kullanarak araştırmışlardır. Modelin tahmin sonuçlarına göre; yabancı yatırımcıların sahipliğinin ROA üzerinde olumsuz bir etkisi olduğunu ortaya koymuşlardır. Ancak yabancı sahipliği ile Tobin's q arasında gerçekleştirilen 5 modelin bir tanesinde negatif ve anlamlı bir ilişki, diğer modellerde ise anlamlı olmayan ilişkiler bulmuşlardır. Benzer bir şekilde Mollah, Al Farooque ve Karim (2012) Bostvana Cumhuriyeti'nde bulunan 19 firmanın 2000-2007 yılları için ortaklık yapısı ile performans arasındaki ilişkiyi EKK yöntemi ile araştırmıştır. Çalışma sonucunda yabancı yatırımcı sahipliği ile ROA arasında pozitif bir ilişki; buna karşın ROE ve
Tobin's q arasında ise anlamlı olmayan bir ilişki gözlemlemişlerdir. Buna karşın Abbasi, Kalantari ve Abbasi (2012) çalışmasında, Tahran Menkul Kıymetler Borsası'nda gıda sektöründe hisse senetleri işlem gören 82 firmanın 2002- 2011 yılları için kurumsal yönetim mekanizmaları ile firma değeri arasındaki ilişkiyi incelemişlerdir. Araştırma sonucunda yabancı yatırımc sahipliği ile Tobin's q arasında pozitif ve anlamlı bir ilişki belirlenmiştir. Bu durumu yazarlar; yabanc yatırımcılar ulusal firmalara yalnızca sermaye getirmemekte aynı zamanda gelişmiş sermaye piyasalarından gelişmekte olan piyasalara gözetim becerilerini ve kendilerini güvence altına alan kurumsal yönetim uygulamalarını getirmeleriyle ilişkilendirmişlerdir.

Moscu (2013) yönetim kurulu özelliklerinin firma performansı üzerindeki etkisini Romanya borsasına kayıtlı firmaların verilerini kullanarak araştırmıştır. Ampirik analizler sonucunda yabancı yatırımcı olması durumunda firmanın ROA ve ROE'si olumsuz yönde etkilendiği tespit edilmiştir. Bayrakdaroğlu (2010) çalışmasında BIST 100'de faaliyet gösteren 72 şirket için ortaklık yapısı ile finansal performans arasındaki ilişkiyi 2005-2009 yılları açısından araştırmıştır. EKK yöntemleri ile gerçekleştirilen regresyon analizleri sonucunda yabancı yatırımcı sahipliği ile ROA arasında negatif bir ilişki; buna karşın ROE ve Tobin's q arasında anlamlı olmayan ilişkileri bulmuştur. 2007-2012 yılları arasında Vietnam Borsasına kayıtı firmalar üzerine yaptıkları çalışmalarında Phung ve Hoang (2013) ise ortaklık yapısı ile firma performansı arasındaki ilişkiyi sabit etkiler modeliyle ölçmüşlerdir. Model sonuçlarında yabancı yatırımcı sahipliği ile ROA ve Tobin's q arasında u şeklinde (u-shaped) bir ilişki belirlemişlerdir.

Özetle çalışmaların önemli bir kısmında yabancı yatırımcı sahipliği ile firma performansı arasında olumlu pozitif bir ilişki tespit edilmiştir. Söz konusu yazarlara göre; yabancı yatırımcılar teknik teknoloji sağlaması yanında, önemli bir genel yönetim katkısı sağlamaktadır. Bununla birlikte yazarlar; yabancı yatırımcıların kendilerinin haklarının korunduğu güvenli ülkelere yatırım yapacaklarını vurgulamışlardır. Ayrıca ülkelerin dışa açıklığı yabancı yatırımcı sahipliğini de artırmaktadır. 
Tablo 2 : Yabancı Yatımcı Sahipliğinin İşletmenin Finansal Performansına Etkisini İnceleyen Araştırmaların Özetlenmesi

\begin{tabular}{|c|c|c|c|c|c|c|c|}
\hline \multirow[t]{2}{*}{ Yazar } & \multirow[t]{2}{*}{ YII } & \multirow[t]{2}{*}{ Ülke } & \multirow[t]{2}{*}{ Dönem } & \multirow{2}{*}{$\begin{array}{l}\text { Firma } \\
\text { Sayısı }\end{array}$} & \multirow[t]{2}{*}{ Model } & \multicolumn{2}{|c|}{$\begin{array}{l}\text { Performans } \\
\text { Ölçümüü }\end{array}$} \\
\hline & & & & & & Tobin's q & Karlılık \\
\hline Barnhart ve Rosenstein & 1998 & $A B D$ & 1990 & 321 & EKK/3EKK/KOR & - & \\
\hline Oxelheim ve Randøy & 2003 & Norveç & 1996-1998 & 132 & EKK/2EKK & $+^{*}$ & \\
\hline Oxelheim ve Randøy & 2003 & İsveç & 1996-1998 & 121 & EKK/2EKK & $+^{*}$ & \\
\hline Choi vd. & 2007 & Kore & $1999-2002$ & 450 & $\mathrm{EKK} / 2 \mathrm{EKK}$ & $+^{*}$ & \\
\hline Cho ve Kim & 2007 & Kore & 1998 & 347 & EKK & & $+^{*}$ \\
\hline Zeitun ve Tian & 2007 & Ürdün & $1989-2002$ & 59 & LOJ & $-*$ & $-/-$ \\
\hline Cornett vd. & 2007 & $A B D$ & $1993-2000$ & 100 & EKK & & $+^{*}$ \\
\hline Lee & 2009 & Kore & $2000-2006$ & 579 & EKK/ ROB & $+^{*}$ & $+^{*}$ \\
\hline Sueyoshi vd. & 2010 & Japonya & $1999-2006$ & 270 & EKK/TOBIT & & $-* /-*$ \\
\hline Bayrakdaroğlu & 2010 & Türkiye & $2005-2009$ & 72 & EKK & + & $-* /+$ \\
\hline Elsayed & 2011 & Misır & $2000-2004$ & 92 & EKMS/EKMK & $t^{*}$ & $+* /+^{*}$ \\
\hline Abbasi vd. & 2012 & İran & $2002-2011$ & 82 & GEKK & $t^{*}$ & \\
\hline Mollah vd. & 2012 & Bostvana & $2000-2007$ & 19 & EKK & + & $+* /+$ \\
\hline Wellalage ve Locke & 2012 & Sri Lanka & 2004-2009 & 152 & GMM & - & $-*$ \\
\hline Moscu & 2013 & Romanya & 2010 & 62 & EKK & & $-/_{-*}$ \\
\hline Phung ve Hoang & 2013 & Vietnam & $2007-2012$ & $475^{a}$ & SEM & $+* /-*$ & $+* /{ }^{*}$ \\
\hline
\end{tabular}

*istatistiksel olarak anlamlı olduğunu göstermektedir.

älgili dönemler arasında ortalama firma sayısını göstermektedir.

REG; çoklu regresyon yöntemini, KOR; korelasyon yöntemini, EKK; en küçük kareler yöntemini, 2EKK; iki aşamalı en küçük kareler yöntemini, 3EKK; üç aşamalı en küçük kareler yöntemini, LOJ; Lojistik regresyon yöntemini, ROB; dirençli (sağlam) tahmincisini, GMM; genelleştirilmiş momentler yöntemini, SEM; sabit etkiler modelini, GEKK; genelleştirilmiş en küçük kareler yöntemi, EKMS; en küçük mutlak sapmalar yöntemini, EKMK; En Küçük Medyan Kareler Yöntemini, TOBIT; tobit modelini, göstermektedir.

\section{METODOLOJi}

$\mathrm{Bu}$ çalışmada Borsa ìstanbul (BIST) imalat sanayide faaliyet gösteren firmalarda yönetim kurulundaki yabancı üye sayısının ve yabancı sahipliğinin finansal performansı üzerindeki etkisi test edilmiştir. Araştırmanın bu bölümünde veri seti ve örneklem ile bilgiler verilerek bağımlı ve bağımsız değişkenler tanıtılmıştır. Daha sonra ise literatürle tutarlı biçimde hipotezler ve ekonometrik modeller geliştirilmiştir.

\subsection{Veri Seti ve Örneklem}

Araştırmada 2002-2012 yıllarına ait BIST imalat sanayide faaliyet gösteren firmaların tamamı ile bir örneklem oluşturulmuştur. Söz konusu yıllar arasında imalat sanayinde kesintisiz faaliyet gösteren toplam 136 firma analize dahil edilmiştir. Bu firmalar 9 alt sektöre ayrılmıştır. İmalat sanayinde yer alan 136 firmanın alt sektörleri Tablo 1'de gösterilmiştir. 
Tablo 3: İmalat Sanayi'de Faaliyet Gösteren Firmaların Sektörlere Göre Dağılımı

\begin{tabular}{|l|c|}
\hline Sektör & Firma Sayısı \\
\hline Gıda, İçi ve Tütün & 21 \\
\hline Dokuma Giyim Eşyası ve Deri & 21 \\
\hline Orman Ürünleri ve Mobilya & 2 \\
\hline Kağıt ve Kağıt Ürünleri, Basım ve Yayın & 10 \\
\hline Kimya, Petrol, Kauçuk ve Plastik Ürünler & 24 \\
\hline Taş ve Toprağa Dayalı Sanayi & 24 \\
\hline Metal Ana Sanayi & 11 \\
\hline Metal Eşya, Makine ve Gereç Yapım & 20 \\
\hline Diğer İmalat Sanayi & 3 \\
\hline Toplam Firma Sayısı & $\mathbf{1 3 6}$ \\
\hline
\end{tabular}

\subsection{Yöntem}

Araştırmada veriler Stata 13.0 programından yararlanarak çözümlenmiştir. Regresyon modelinin tahmininde heteroskedasite, otokorelasyon ve birimler arasında korelasyon olması durumunda hata terimin varyansı birim matrise eşit olmamaktadır. $\mathrm{Bu}$ durum modelin tutarsızlığına sebep olmakta ve etkinliği etkilemektedir. Bu nedenlerden dolayı modelde heteroskedasite, otokorelasyon ve birimler arasında korelasyondan en az birisi olması durumunda ya parametre tahminlerine dokunmadan standart hataların düzetilmesi (dirençli standart hatalar elde edilmeli) ya da varlıkları halinde uygun yöntemler ile tahmin edilmesi gerekir (Tatoğlu, 2013: 242). Literatürde regresyon çözümlenmesinde OLSyöntemi sıkça tercih edilmesine rağmen bu araştırmada yukarıda bahsedilen nedenlerden dolayı Dirençli tahminciler kullanılmıştır. Literatürde kullanılan dirençli tahminciler Huber Eicker White $(1967,1967$, 1980), Wooldridge (2002), Newey-West (1987, 1994), Parks-Kmenta (1967, 1986), Beck-Katz (1995), Driscoll ve Kraay (1998) tarafından önerilmiştir. Çalışmada, değişen varyans, otokorelasyon veya birimler arası korelasyonun (yatay kesit bağımlılığının) varlığına karşı dirençli olduğu için ve $T<N$ (yıl küçüktür gözlem sayısı) durumunda uygulanabildiğinden Beck-Katz (1995) tarafından geliştirilen dirençli tahminci tercih edilmiştir.

\subsection{Değişkenler}

Çalışmada dört adet bağımlı değişken (ROA, ROE, TOBIN ve ALTMAN) ve beş adet bağımsız değişken (YKYU, YABPAYI, KALDIRAC, VARLIK ve YAS) kullanılmıştır. Söz konusu değişkenlere ilişkin bilgiler aşağıda ifade edilmiştir.

\subsubsection{Bağımlı Değişkenler}

Yönetim kurulundaki yabancı üye sayısının ve yabancı sahipliğinin firmaların finansal performansına etkisini ölçen çalışmalarda iki farklı performans göstergesi kullanılmıştır. Yermack (1996); Postma, Ees ve Sterken (2003); Filatotchev, Yung-Chih ve Piesse (2005); Cho ve Kim (2007); Yu (2008); Arosa, Iturralde ve Maseda (2010); Elsayed (2011); Fauzi ve Locke (2012); Vo ve Phan (2013); Rehman ve Shah (2013); Bhagat ve Bolton (2013); Cook (2013) gibi yazarlar finansal performans göstergeleri olarak muhasebe temelli göstergeler (ROA ve ROE) kullanmışlardır. Barhart ve Rosenstein (1998); Vafeas ve Theodorou (1998); Himmelberg, Hubbard ve Palia (1999); Demsetz ve Villalonga (2001); Davies, Hillier ve McColgan (2002); Mak ve Kusnadi (2005); Beiner vd. (2006); Mura (2007); Ehikioya (2009); Böhren ve Ström (2010); Horváth ve Spirollari (2012); Rad vd. (2013); Bhagat ve Bolton (2013); Kumar ve Singh (2013) gibi yazarlar ise piyasa temelli performans göstergesinden (Tobin's q) yararlanmışlardır. Bu araştırmada bağımlı değişken olarak hem muhasebe (ROA ve ROE) hem de piyasa esaslı (Tobin's q) finansal performans göstergeleri kullanılmıştır. Diğer bağımlı değişken olarak ise son yıllarda kurumsal yönetim uygulamalarının finansal performans üzerindeki etkisini inceleyen çalışmalarda (Örn. Bonna, 2012) Z Altman skoru bağımlı değişken olarak kullanılmıştır. Z Altman skoru firmaların iflas riskini veya finansal başarısızlık (financial distress) riskini ölçmeye yaramaktadır. 
Z Altman skorunun yükselmesi, azalması veya iflas riskinin artması, azalması durumunda firmalarda yabancı sahipliğinin ve YKYU sayısının nasıl değiştiğini belirlemek amacıyla modele eklenmiştir. Araştırmada kullanılan bağımlı değişkenler şu şekildedir:

Z Altman Skoru (ALTMAN) formülü şu şekilde hesaplanmıştır (Altman, 2000)

$Z$ Skoru $=X_{1}=0,717$ (Çalışma Sermayesi / Toplam Varlıklar)

$X_{2}=+0,847$ (Geçmiş̧ Yıl Karları / Varlıklar)

$X_{3}=+3,107$ (Faiz ve Vergi Öncesi Kazanç / Toplam Varlıklar)

$X_{4}=+0,420$ Hisse Senetlerinin Defter Değeri/Borcun Defter Değeri

$X_{5}=+0,998$ (Satış Gelirleri / Toplam Varlıklar)

Varlık Karlıığı (ROA): Dönem net kârının toplam varlıklara oranlanmasıyla hesaplanmıştır. Bu oran firmaların karlılığını ve yönetimin yeteneğini gösteren bir orandır.

Öz Sermaye Kârlılı̆̆ı (ROE): Dönem net kârının öz sermaye toplamına oranlanmasıyla hesaplanmıştır. $\mathrm{Bu}$ oran ortaklarca firmaya yapılan yatırımın etkin kullanılıp kullanılmadığını gösterir. Bu oranının ROA'dan farkı, finansal kaldıraç seviyesinin etkisidir. Finansal kaldıraç iyi kullanılmışsa ROE oranı yüksek olacaktır (Okka, 2009: 112).

Tobin's q (TOBIN) : Firmanın piyasa değerinin defter değerine oranlanması ile elde edilmiştir. Bu oran yatırımcıların şirketi nasıl değerlendiğine dair bulgu verir. Yatırımcılar tarafından beğenilen şirketler düşük risk, yüksek büyüme ve yüksek (TOBIN) oranına sahiptir (Brigham ve Houston, 2011: 112).

\subsubsection{Bağımsız Değişkenler}

YKYU: Yönetim kurulunda yabancı üyenin olup olmadığıdır. Firmalarda yönetim kurulunda yabancı uyruklu üye varsa 1 , yoksa 0 olarak tanımlanmıştır. Kaynak bağımlıı̆ğı teorisine göre; yönetim kurulunda etnik olarak çeşitliliğin arttırıması, işletmenin kaynaklardaki çeşitliliğini arttırmasını sağlayacak böylelikle işletme performansını olumlu yönde etkileyecektir. Vekalet teorisine göre ise; yönetim kurulunda bağımsız olmayan üyeler ile bağımsız üyeler arasında bir dengenin olması gerekmektedir. Bu denge içinde bulunan bağımsız yönetim kurulu üyeler üst düzey yönetimi daha etkili bir şekilde kontrol edip gözetleyecektir (Ocak, 2013: 109). Özetle vekâlet teorisine göre; yönetim kurulunda, etnik köken açısından çeşitliliğin olması halinde yönetim kurulunun bağımsızlığını arttıracak ve böylelikle işletme performansı olumlu yönde etkilenecektir.

YABPAYI: YabancI yatırımciların elinde bulundurduğu sermaye tutarının, toplam sermayeye bölünmesiyle elde edilmiştir. Yabancı yatırımcıların elinde bulundurduğu sermaye oranı firmaların sahiplik yapısını etkilemektedir. Kaynak bağımlılığı teorisine göre; işletmelerin sermaye ihtiyacını daha kolay elde edebilmeleri için yabancı yatırımcıların ülkeye teşvikinin artırılması gerekmektedir.

VARLIK: Firmaların toplam varlıklarıdır. Diğer değişkenler ile uyumlu olması için logaritması alınarak modele dahil edilmiştir. Toplam varlıklar; firma büyüklüğünü gösterir ve finans literatürün önemli bir kısmında karlılık ve performans ölçmede bağımsız veya kontrol değişken olarak kullanılmıştır. Büyüklük göstergesi olarak Saliha ve Abdessatar (2011), Obradovich ve Gill (2013), Vo ve Phan (2013), Swastika (2013) gibi yazarlar firma büyüklük göstergesi olarak "Toplam Varlıkları" kullanmışlardır

KALDIRAC: Firmaların toplam borçlarının toplam varlıklarına oranlanmasıyla elde edilmiştir. Bu oran varlıkların yüzde kaçının borçlarla finanse edildiğini göstermektedir. Toplam borç oranı yüksek olan işletmelerin faaliyetlerini devam ettirebilmesi borçlara bağlıdır. Bu oranın çok yüksek olması firmanın riskliliğinin artmasına ve mali sıkıntıya düşmesine hatta iflas etmesine neden olabilir. Özellikle kredi verenler açısından bu oranın düşük olması istenir (Elitaş ve Doğan, 2013: 46). Bununla birlikte kaldıraç oranının değişmesi firmaların ortaklık yapısını da değiştirmektedir.

YAS: Firmaların kuruluş yılı ile cari yıl arasındaki farktır. Yönetim kurulundaki yabancı üye sayısı ve yabancı sahipliği ile firma performansı arasındaki ilişkiyi ölçen birçok çalışmada (örn: Peng, Zhang ve Li 2007, Wang ve Clift 2009, Rashid vd. 2010, Ujunwa 2012, Younas, Mahmood ve Saeed 2013, Kumar ve Singh 2013) firma yaşı bağımsız değişken olarak kullanılmıştır.

Sonuç olarak araştırmada kullanılan değişkenlerin (değişken (ROA, ROE, TOBIN, ALTMAN, YKYU, YABPAYI, KALDIRAC, VARLIK ve YAS) özeti Tablo 4'te gösterilmiştir. 
Tablo 4: Analizde Kullanılan Değişkenler

\begin{tabular}{|c|c|c|}
\hline Değişkenler & Tanımlamalar & Kodları \\
\hline \multicolumn{3}{|c|}{ Bağımlı Değişkenler } \\
\hline Varlık Karlılığı & Net Kar/Toplam Varlıklar & ROA \\
\hline Özsermaye Karlılığı & Net Kar/Toplam Özsermaye & ROE \\
\hline Tobin's q & Piyasa Değeri/Defter Değeri & TOBIN \\
\hline \multirow[t]{2}{*}{ Z Altman } & Z Altman Skoru & ALTMAN \\
\hline & \multicolumn{2}{|c|}{ Temel Bağımsız Değişkenler } \\
\hline Yabancı YK varlığı & YKYU varsa 1 , yoksa 0 & YKYU \\
\hline \multirow[t]{2}{*}{ Yabancı Sahipliği } & Yabancı Sermaye Tutarı / Toplam Sermaye & YABPAYI \\
\hline & \multicolumn{2}{|c|}{ Kontrol Değişkenler } \\
\hline Firma Büyüklüğü & Toplam Varlıkların Logaritması & VARLIK \\
\hline Borç Seviyesi & Toplam Borçlar/Toplam Varlıklar & KALDIRAC \\
\hline Firma Yaşı & Cari yıl-Kuruluş yılı & YAS \\
\hline
\end{tabular}

\subsection{Araştırmanın Modeli ve Hipotezler}

Çalışmanın kapsamı ve amacı çerçevesinde aşağıdaki modeller geliştirilmiş olup, yönetim kurulundaki yabancı üye sayısının ve yabancı sahipliğinin firma performansı üzerindeki etkisi araştırılmaya çalışılmıştır.

Şekil 1: Kavramsal Çerçeve

\begin{tabular}{|l|l|}
\hline $\begin{array}{l}\text { Yönetim } \\
\text { Kurulundaki } \\
\text { Yabancı Üye Sayısı }\end{array}$ & $\begin{array}{c}\text { Firma } \\
\text { Performansı }\end{array}$ \\
\hline Yabancı Sahipliği & ROA \\
\hline $\begin{array}{l}\text { Kontrol } \\
\text { Değişkenleri } \\
\text { Firma Büyüklüğü } \\
\text { Kaldıraç } \\
\text { Firma Yaşı }\end{array}$ \\
\hline
\end{tabular}

Çalışmada test edilecek hipotezler aşağıda gösterilmiştir. Literatürle tutarlı bir şekilde 8 hipotez geliştirilmiştir.

$H_{1}=$ Yabancı yönetim kurulu üyesi sayısı ile ROA arasında pozitif bir ilişki vardır.

$\mathrm{H}_{2}=$ Yabancı yönetim kurulu üyesi sayısı ile ROE arasında pozitif bir ilişki vardır.

$\mathrm{H}_{3}=$ Yabancı yönetim kurulu üyesi sayısı ile Tobin's $q$ oranı arasında pozitif bir ilişki vardır.

$\mathrm{H}_{4}=$ Yabancı yönetim kurulu üyesi sayısı ile $Z$ Altman skoru arasında pozitif bir ilişsi vardır.

$H_{5}=$ Yabancı sahipliği ile ROA arasında pozitif bir ilişki vardır.

$H_{6}=$ Yabancı sahipliği ile ROE arasında pozitif bir ilişki vardır.

$H_{7}=$ Yabancı sahipliği ile Tobin's q oranı arasında pozitif bir iliş̧ki vardır.

$H_{8}=$ Yabancı sahipliği ile Z Altman skoru arasında pozitif bir ilişki vardır. 


\section{BULGULAR}

Tablo 5'te analizlerde kullanılan bağımlı ve bağımsız değişkenlere ait tanımlayıcı istatistik sonuçları yer almaktadır. Tablo 5'ten görüldüğü gibi BIST imalat sanayide faaliyet gösteren ve analiz kapsamında incelenen firmaların ortalama varlık karlılığı (ROA) \%2,41 olarak tespit edilmiştir. Cavaco vd. (2013) Fransa'da bulunan firmaların 2003-2011 yılları için ROA'sını \%3 olarak, Vo ve Phan (2013) 2006-2011 yıllarını kapsayan ve toplam 77 Vietnam firması üzerine yapmış oldukları araştırmalarında ROA'yı \%11,8 olarak hesaplamışlardır. Obradovich ve Gill (2013) 2009-2011 yıllarında Newyork borsasında imalat ve hizmet sektöründe faaliyette bulunan 333 firmanın ROA'sını \%7; Fauzi ve Locke (2012) Yeni Zelanda Menkul Kıymetler Borsası'nda faaliyet gösteren 79 firmanın 2007-2011 yılları için ortalama ROA'sını \%4 olarak bulmuşlardır. BIST firmalarının göreceli olarak yukarıda bahsi geçen ülkelerde bulunan firmalardan ortalama ROA'sı daha düşük olduğu söylenebilir.

Tablo 5: Tanımlayıcı İstatistikler

\begin{tabular}{|c|c|c|c|c|c|}
\hline Değişkenler & Göz. Sayısı & Ortalama & Std. Sapma & Minimum & Maksimum \\
\hline ROA & 1496 & .0241918 & .1916635 & -4.452 & 2.993 \\
\hline ROE & 1496 & .0665308 & 2.255487 & -30.303 & 12.933 \\
\hline TOBIN & 1496 & 1.984391 & 4.309919 & .147 & 109.462 \\
\hline ALTMAN & 1496 & 2.52512 & 4.202251 & -13.252 & 61.252 \\
\hline YKYU & 1496 & 0,940 & 3.2541 & 0.00 & 8.00 \\
\hline YABPAYI & 1496 & 12.16383 & 25.46482 & 0 & 99.36 \\
\hline VARLIK & 1496 & 19.0348 & 1.467308 & 15.328 & 23.563 \\
\hline KALDIRAC & 1496 & .461363 & .2292338 & .006 & .998 \\
\hline YAS & 1496 & 36.11029 & 11.83778 & 3 & 77 \\
\hline
\end{tabular}

Tablo 5'te ikinci bağımlı değişken olan öz sermaye karlılığının (ROE) ortalaması \%6,6 olarak belirlenmiştir. Cavaco vd. (2013) Fransa firmaları için \%9; Velnampy (2013) Sri Lanka firmaları için \%4,89; Rehman ve Shah (2013) Pakistan firmaları için \%16,8; Taghizadeh ve Saremi (2013) Malezya firmaları için \%11,56 olarak hesaplamışlardır. Üçüncü bağımlı değişken olan Tobin's q oranının (TOBIN) ortalaması 1,98'tir. Obradovich ve Gill (2013) ABD firmaları için 3,08; Saravanan (2012) Hindistan firmaları için 2,11; Guest (2009) İngiltere firmaları için 1,53 olarak hesaplamışlardır. Son bağımlı değişken Z Altman skoru ise 2,52 olarak elde edilmiştir. Bonna (2012) ABD firmaları için 3,24 olarak bulmuştur. Altman (2000) yaptığı çalışmasında Hisse Senetlerinin Defter Değeri /
Borcun Defter Değeri (X4) değişkenini güncellemiştir. Çalışmaların bir kısmı bu güncellemeyi dikkate almadan hesaplamalarından dolayı Z Altman skoru farklı ülke firmaları açısından sağlıklı bir karşılaştırııma yapılamamıştır.

Bağımsız değişkenler incelendiğinde BIST İmalat sanayide faaliyet gösteren firmaların \%70'inde yönetim kurulunda yabancı uyruklu üye bulunmazken \%30'unda ise yönetim kurulunda yabancı uyruklu üye mevcuttur. Yönetim kurulundaki yabancı üye sayısı ortalaması 0,94 olarak tespit edilmiştir. Yabancı sahipliği ise \%12,16 olarak belirlenmiştir. Verilerin analizinde yabancı sahipliğinin yıllara göre arttığı görülmüştür. 
Tablo 6: Korelasyon Tablosu

\begin{tabular}{|l|c|c|c|c|c|c|c|c|c|}
\hline & ROA & ROE & TOBIN & ALTMAN & YKYU & YABPAYI & VARLIK & KALDIRAC & YAS \\
\hline ROA & 1.00 & & & & & & & & \\
\hline ROE & 0.66 & 1.00 & & & & & & & \\
\hline TOBIN & 0.01 & 0.01 & 1.00 & & & & & & \\
\hline ALTMAN & 0.34 & 0.04 & 0.01 & 1.00 & & & & & \\
\hline YKYU & -0.04 & -0.10 & 0.21 & 0.05 & 1.00 & & & & \\
\hline YABPAYI & -0.04 & 0.19 & 0.25 & 0.08 & 0.26 & 1.00 & & & \\
\hline VARLIK & 0.16 & 0.09 & -0.07 & 0.13 & 0.16 & -0.10 & 1.00 & & \\
\hline KALDIRAC & -0.33 & -0.14 & 0.08 & -0.42 & -0.08 & 0.12 & -0.07 & 1.00 & \\
\hline YAS & -0.09 & 0.01 & -0.01 & -0.05 & 0.01 & -0.02 & 0.22 & -0.02 & 1.00 \\
\hline
\end{tabular}

Tablo 6'da bağımlı ile bağımsız değişkenler arasındaki ilişkiyi gösteren korelasyon tablosu gösterilmiştir. Korelasyon tablosunda bağımsız değişkenler arasında önemli bir ilişkinin olmadığı görülmektedir. Bu durum modelin güvenirliliğini artırmaktadır.

Araştırmada serilerin durağan olup olmadığı araştırılmıştır. Değişkenler arasında ekonometrik olarak anlamlı ilişkiler elde edilebilmesi için serilerin durağan olması gerekmektedir. Bu araştırmada değişkenlerin normal dağılıma sahip olmayan (parametrik olmayan) analizlerde ve birimler arası korelasyon olduğu durumlarda uygun biryöntem olan birinci kuşaklardan Fisher ADF Kök Testi kullanılmıştır. Ayrıca Fisher ADF Kök Testi'nin alternatifi olan LLC (2002) testi kullanılmıştır. Her iki kök test sonuçları da serilerin durağan olduğunu göstermektedir. Sonuçlar Ek 1'de gösterilmiştir.

Panel veri setinde modelin sabit etkiler mi yoksa rassal etkiler mi olacağına karar verilmesi amacıyla Hausman testine başvurulmuştur. Hausman testi sonuçları incelendiğinde tespit edilen olasılık değeri 0,05 'ten küçük olmasından dolayı sabit etkiler modelinin tercih edilmesinin daha doğru sonuçlar vereceğini göstermektedir. Sonuçlar Ek 2'de gösterilmiştir. Ayrıca otokorelasyon olup olmadığı test etmek amacıyla panel veri setleri için geliştirilmiş Bhargava, Franzini ve Narendranathan'ın Durbin Watson testi ve Baltagi-Wu'nun Yerel En İyi Değişmez Testi (LBI) kullanılmıştır. Test sonuçları incelendiğinde dört model içinde otokorelasyon olduğu $(p<0.05)$ görülmektedir. Sonuçlar Ek 3'te gösterilmiş̧ir

Araştırmada sabit etkiler modelinde yatay kesit bağımlılığını ölçmek ve birimler arası korelasyonu test etmek için Pesaran CD testi kullanılmıştır. Sonuçlar incelendiğinde modellerin olasılık değeri 0.05 'ten küçük olduğu için yatay kesit bağımlılığı vardır. Sonuçlar Ek 4'te gösterilmiştir. Ayrıca araştırmada çoklu varyans problemi olup olmadığını ölçmek için Değiştirilmiş Wald Testi kullanılmıştır. Geliştirilen modeller için olasılık değeri 0.05 'ten küçük olduğu için değişen varyans sorunu mevcuttur. Sonuçlar Ek 5 'te gösterilmiş̧ir 
Tablo 7: Dirençli (Robust) Tahmin Sonuçları

\begin{tabular}{|c|c|c|c|c|}
\hline $\begin{array}{l}\text { DEĞiŞKENLER ve } \\
\text { PARAMETRELER }\end{array}$ & $\begin{array}{l}\text { Model } 1 \\
\text { ROA }\end{array}$ & $\begin{array}{l}\text { Model } 2 \\
\text { ROE }\end{array}$ & $\begin{array}{c}\text { Model } 3 \\
\mathbf{Q}\end{array}$ & $\begin{array}{l}\text { Model } 4 \\
\text { ALTMAN }\end{array}$ \\
\hline YKYU & -0.04 & -1.25 & $2.37^{* *}$ & 0.57 \\
\hline YABPAYI & -0.14 & $-2.77^{* *}$ & $2,68^{* * *}$ & 0,10 \\
\hline KALDIRAC & $-13.89^{* * *}$ & $-2.00^{* *}$ & -1.20 & $-12.50^{* * *}$ \\
\hline VARLIK & $8.98^{* * *}$ & $2.00^{* *}$ & 1.09 & $15.97^{* * *}$ \\
\hline YAS & $-2.69^{* * *}$ & -0.45 & -0.06 & $-2.26^{* *}$ \\
\hline Sabit (c) & $3.86^{* * *}$ & $-3.24^{* * * *}$ & $3.98^{* * *}$ & $4,85^{* * *}$ \\
\hline Gözlem Sayısı & 1496 & 1496 & 1496 & 1496 \\
\hline Firma Gözlem Sayısı & 136 & 136 & 136 & 136 \\
\hline Olasılık $(p)$ & 0,00000 & 0,00000 & 0,00000 & 0,00000 \\
\hline WaldChi ${ }^{2}$ & 197.12 & 40.27 & 289.97 & 737.41 \\
\hline $\mathrm{R}^{2}$ & 0.1164 & 0.0262 & 0.1982 & 0.5043 \\
\hline
\end{tabular}

***,** ve * sırasıyla \% 1, \% 5 ve \% 10 düzeyinde anlamlılı̆ı göstermektedir.

Tablo 7'de değişen varyans, otokorelasyon veya birimler arası korelasyonun varlığına dirençli olan Beck-Katz (1995) tarafından geliştirilen Robust (Dirençli) tahmincisinin sonuçları gösterilmiştir. Modellerin sonuçları incelendiğinde yönetim kurulundaki yabancı üye varlığı $R O A, R O E$ ve $A L T M A N$ üzerinde etkili değildir. Ancak $Y K Y U$ sayısı piyasa esaslı performans göstergesi olan Tobin's q oranı üzerinde etkilidir. YKYU sayısı ile TOBIN arasında pozitif bir ilişki tespit edilmiştir. Başka bir ifade ile $Y K Y U$ sayısı arttıkça firmaların piyasa değeri artmaktadır. Diğer bağımsız değişken olan yabancı sahipliği ile ROA ve ALTMAN arasında istatistiksel olarak anlamlı bir ilişki yoktur. Buna karşın YABPAYI ile ROE arasında negatif bir ilişki; buna karşın, TOBIN ile YABPAYI arasında pozitif bir ilişki elde edilmiştir. Yabancı sahiplik seviyesi arttıkça öz sermaye başına düşen karlılıkta azalmakta ancak firmanın piyasa değeri yükselmektedir. Sonuç olarak yönetim kurulundaki yabancı üyesi ve yabancı ortaklığın bulunması işletmenin piyasa değerine olumlu katkı yapmaktadır.

Modeldeki kontrol değişkenleri incelendiğinde kaldıraç oranı ile ROA, ROE ve ALTMAN arasında negatif bir ilişki gözlenmiştir. Diğer kontrol değişken firma büyüklük göstergesi olan toplam varlıklar ile $R O A$, $R O E$ ve $A L T M A N$ arasında pozitif bir ilişki belirlenmiştir. Başka bir ifade ile firma büyüklüğünün artması varlık ve öz sermaye karlılığını artırmakta ancak finansal başarısızlık riskini azaltmaktadır.
Diğer kontrol değişken olan firma yaşı ile ALTMAN skoru ve $R O A$ arasında negatif bir ilişki elde ediliştir.

\section{GENEL DEĞERLENDIRME, SONUÇ ve ÖNERILER}

$\mathrm{Bu}$ araştırmada yönetim kurulundaki yabancı üye sayısının ve yabancı sahipliğinin finansal performans üzerindeki etkisini tespit etmektir. Bu amaç doğrultusunda araştırmada 2002-2012 yıllarına ait Borsa İstanbul (BIST) imalat sanayide faaliyet gösteren 136 firmanın verilerinden yararlanılmıştır. Ampirik analizlerde Beck-Katz (1995) tarafından geliştirilen Robust (Dirençli) tahmincisi kullanılmıştır.

Geliştirilen modellerin sonuçları incelendiğinde yönetim kurulundaki yabancı üye sayısı ile muhasebe ve piyasa esaslı performans göstergeleri arasında farklı sonuçlar tespit edilmiştir. $Y K Y U$ sayısı ile $R O A$, $R O E$ ve $Z$ Altman Skoru arasında istatistiksel olarak anlamlı olmayan bir ilişki tespit edilmiştir. Buna karşın YKYU sayısı ile piyasa esaslı performans göstergesi olan Tobin's q arasında pozitif ve istatistiksel olarak oldukça anlamlı bir ilişki tespit edilmiştir. Araştırmada geliştirilen $\mathrm{H}_{3}$ hipotezi kabul edilmiş ancak $\mathrm{H}_{1}, \mathrm{H}_{2}$ ve $\mathrm{H}_{4}$ hipotezleri ise reddedilmiştir. $\mathrm{Bu}$ sonuçlar kaynak bağımlılığı ve vekâlet teorisini destekler niteliktedir. Yönetim kurulunda etnik köken, kültürel altyapı bakımından çeşitliliğin arttırılması, yönetim kurulunun bağımsızlığını arttıracaktır. 
Yönetim kurulunda çeşitliliğin arttırılması neticesinde ise işletmenin performansı olumlu yönde etkileyecektir. Sonuç olarak yönetim kurulundaki yabancı üye(ler) bulunan işletmeler yatırımcı gözünde daha değerli olduğu söylenebilir.

YKYU sayısı ile performans arasındaki ilişkiyi ölçen çalışmalar incelendiğinde Oxelheim ve Randøy (2003); Ujunwa (2012); Shukeri, Shin ve Shaari (2012); Kondrunina (2013) ile aynı yönde sonuçlar tespit edilirken Masulis, Randøy vd. (2006); Rose (2007); Choi, Park ve Yoo (2007); Shukeri, Shin ve Shaari (2012); Wang ve Xie (2012); Cavaco vd. (2013) ters yönde bir ilişki elde edilmiştir.

Yabancı Sahipliği (YABPAYI) ile firma performansı arasındaki ilişkiyi incelendiğinde farklı sonuçlar tespit edilmiştir. Yabancı sahipliği ile ROA ve Z Altman skoru arasında anlamlı olmayan bir ilişki; buna karşın $R O E$ ve Tobin's q oranı ile YABPAYI arasında istatistiksel olarak anlamlı bir ilişki elde edilmiştir. Araştırmada geliştirilen $\mathrm{H}_{7}$ hipotezi kabul edilmiş ancak $\mathrm{H}_{5}, \mathrm{H}_{6}$ ve $\mathrm{H}_{8}$ hipotezleri ise reddedilmiştir. Yabancı sahipliğinin artması işletmelerin öz sermaye başına düşen karlılığını azaltırken piyasa değerini yükseltmektedir. Öz sermaye karlılığı ile yabancı sahipliği arasında negatif bir ilişki belirlenmesi; yabancı ortak bulunan firmalarda kaldıraç oranının daha düşük olması ile açıklanabilir. Bununla birlikte finansal yönetimin amacı; işletmenin piyasa değerinin maksimum yapılmasıdır. Yabancı ortak(lar) bulunan işletmelerin bu amacı daha iyi bir şekilde gerçekleştirdikleri söylenebilir. Yatırımcılar özellikle sermaye kazancı elde etmek istiyorsa, yabancı sahipliği olan firmalara yönelmelidir. Sonuç olarak kaynak bağımlılığı teorisi ile tutarlı bir şekilde yabancı sahipliği firma değerini artırıcı bir unsurdur. Bununla birlikte yabancı yatırımcıların kendilerinin haklarının korunduğu güvenli ülkelere yatırım yapmaktadırlar. Ayrıca ülkelerin dışa açıklık seviyesi de yabancı yatırımcı sahipliğini artırmaktadır.

Yabancı sahipliği ile performans arasındaki ilişkiyi ölçen çalışmalar incelendiğinde Oxelheim ve Randøy (2003); Choi, Park ve Yoo (2007); Lee (2009); Elsayed (2011); Phung ve Hoang (2013) ile aynı yönde sonuçlar elde edilirken Barnhart ve Rosenstein (1998); Zeitun ve Tian (2007); Mollah, Al Farooque ve Karim (2012); Wellalage ve Locke (2012); Moscu (2013) ile farklı yönde sonuçlar belirlenmiştir.

YKYU sayısı ve yabancı sahipliği ile finansal performans arasındaki ilişkiyi inceleyen bu araştırmanın bir takım kısıtları bulunmaktadır. Öncelikle çalışmanın bulguları; Borsa İstanbul'da imalat sanayide faaliyette bulunan firmalar açısından yorumlanmalıdır. Ayrıca firmaların 2002-2012 yıllarına ait verilerinden yararlanılması çalışmanın başka kısıtıdır. İmalat sanayide 2013 yılı sonu itibariyle 173 adet firma faaliyet göstermektedir. Bu çalışmada 2012-2012 yılları arasında kesintisiz olarak faaliyet gösteren 136 firmanın verilerinden yararlanılmıştır. Görüldüğü gibi imalat sanayide bulunan tüm firmalar analize dâhil edilmemiş olması da çalışmanın bir diğer kısıttır. Gelecek çalışmalarda farklı sektörler veya imalat sanayide bulunan alt sektörler açısından benzer araştırmalar yapılabilir.

\section{KAYNAKLAR}

Abbasi, M., Kalantari E. ve Abbasi H. (2012) "Impact of Corporate Governance Mechanisms on Firm Value Evidence from the Food Industry of Iran" Journal of Basic and Applied Scientific Research, 5: 4712-4721.

Altman, E. I. (2000) "Predicting Financial Distress of Companies:Revisiting The Z-Score and Zeta Models" http://pages.stern.nyu.edu/ ealtman/Zscores.pdf (03.08.2014).

Arosa B., Iturralde T. \& Maseda A. (2010) "Outsiders on The Board of Directors and Firm Performance: Evidence from Spanish Non-Listed Family Firms" Journal of Family Business Strategy, 1: 236- 245.

Aysan, M. A. (2007). Muhasebe ve Kurumsal Yönetim. Muhasebe ve Finansman Dergisi, Sayı: 35, 17-24.
Barnhart, S. W. ve Roseinstein, S. (1998) "Board Composition, Managerial Ownership and Firm Performance: An Empirical Analysis" The Financial Review, 33: 1- 16.

Bayrakdaroğlu, A. (2010) "Mülkiyet Yapısı ve Finansal Performans: IMKB Örneği" Ekonomi Bilimleri Dergisi, 2(2): 11- 20.

Beck N. ve Katz, J. N. (1995) "What To Do (and Not To Do) with Times-Series-Cross-Section Data in Comparative Politics" American Political Science Review, 89(3): 634-647.

Beiner, S., Drobetz, W., Schmid, M. M. ve Zimmermann, H. (2006) "An İntegrated Framework of Corporate Governance and Firm Valuation" European Financial Management, 12: 249- 283. 
Bhagat, S. ve Bolton, B. (2013) "Director Ownership, Governance and Performance" Journal of Financial and Quantitative Analysis, 48(1): 1- 33.

Bonna, K. A. (2012) "The Impact of Corporate Governance on Corporate Financial Performance" Walden University, Applied Management ve Decision Sciences: Finance, Doctor of Philosophy.

Brigham, E. F ve Houston Joel F. (2011) "Fundamentals of Financial Management" Concise 7th Edition.

Cavaco, S., Challe, E., Crifo, P., Reberioux, A. ve Roudaut, G. (2013) "Board Independence and Operating Performance: Analysis On (French) Company and Individual Data" Departement D'economie, Ecole Polytechnique Centre National De La Recherche Scientifique, http://econpapers.repec.org/paper/ drmwpaper/2014-2.htm (01.07.2014).

Cho, D. S. ve Kim, J. (2007) "Outside Directors, Ownership Structure and Firm Profitability in Korea" Corporate Governance: An International Review, 15: 239- 250.

Choi, J. J., Park, S.W. ve Yoo, S. S. (2007) "The Value of Outside Directors: Evidence from Corporate Governance Reform in Korea" Journal of Financial and Quantitative Analysis, 42(4): 941- 962.

Cook, R. (2013) "The Relationship between Corporate Governance Practices and Firm Performance in the Junior Canadian Life Sciences Sector" Saint Mary's University, Master of Business Administration, Halifax, Nova Scotia, Canada.

Cornett, M. M., Marcus A. J., Saunders, A. ve Tehranian, H. (2007) "The Impact of Institutional Ownership on Corporate Operating Performance" Journal of Banking \& Finance, 31: 1771- 1794.

Davies, J. R., Hillier, D. ve McColgan, P. (2002) "Ownership Structure, Managerial Behaviour and Corporate Value" http://citeseerx.ist.psu.edu/ viewdoc/ download?doi=10.1.1.202.5202\&rep= rep1\&type=pdf (02.03.2014).

Demsetz, H. ve Villalonga, B. (2001) "Ownership Structure and Corporate Performance" Journal of Corporate Finance, 7: 209- 233.

Driscoll, J. C. ve Kraay, A.C. (1998) "Consistent Covariance Matrix Estimation with Spatially Dependent Panel Data" Review of Economics and Statistics, 80: 549- 560.

Ehikioya, B. I. (2009) "Corporate Governance Structure and Firm Performance in Developing Economies: Evidence from Nigeria" Corporate Governance, 9(3): 231- 243.
Eicker, F. (1967) "Limit Theorems for Regression with Unequal and Dependent Errors" Proceedings of the Fifth Berkeley Symposium on Mathematical Statistics and Probability. Berkeley: University of California Press.

Elitaş B. L. ve Doğan M. (2013) "Sermaye Yapısını Belirleyen Faktörler: İmkb Sigorta Şirketleri Üzerine Bir Araştırma" Muhasebe Bilim Dünyası Dergisi, 15(2): 41-57.

Elsayed, K. (2011) "Board Size and Corporate Performance: The Missing Role of Board Leadership Structure" Journal of Management \& Governance, 15(3): 415- 446.

Fauzi, F. ve Locke, S. (2012) "Board Structure, Ownership Structure and Firm Performance: A Study of New Zealand Listed-Firms" Asian Academy of Management Journal of Accounting and Finance, 8(2): 43- 67.

Filatotchev, I., Yung-Chih. L. ve Piesse, J. (2005) "Corporate Governance and Performance in Publicly Listed, Family-Controlled Firms: Evidence from Taiwan" Asia Pacific Journal of Management, 22: 257283.

Himmelberg, C. P., Hubbard, R. G. ve Palia, D. (1999) "Understanding the Determinants of Managerial Ownership and the Link Between Ownership and Performance" Journal of Financial Economics, 53(3): 353- 384.

Huber, P. J. (1967) "The Behavior of Maximum Likelihood Estimates under Nonstandard Conditions, In Proc" Fifth Berkeley Symposium on Mathematical Statistics and Probability, University of California Press, Berkeley, 221- 233.

Karabıyık, H. (2011) “Türkiye'de Firma Büyüklüğü Ve Sahiplik Yapısını Etkileyen Sektöre Özgü Firma Belirleyicilerinin Analizi: IMKB'de Sektörel Karşılaştırma" (Yayınlanmamış Yüksek Lisans Tezi). Atılım Üniversitesi, Ankara.

Kargın, S. (2006) "Temettü Politikasının Temsil Maliyetleri Üzerindeki Etkisi ve Kurumsal Yönetime Katkısı" (Yayınlanmamış Doktora Tezi). Celal Bayar Üniversitesi, Manisa.

Kmenta, J. (1986) "Elements of Econometrics" (2nd edn). New York: Macmilan Publishing Company.

Kondrunina, K. (2013) "International Diversity of Boards in Ukraine: Implications for Corporate Governance and Performance" http://www.eerc. ru/Selected/Selected_WS35/Proposal_Kondrunina (11.02.2014). 
Kumar, N. ve Singh, J.P. (2013) “Effect of Board Size and Promoter Ownership on Firm Value: Some Empirical Findings from India" Corporate Governance, 13(1): 8898.

La Porta, R., Lopez-De-Silanes, F. ve Shleifer, A. (1999) "Corporate Ownership Around the World" Journal of Finance, 54: 471-517.

Lee, S. (2009). Corporate Governance and Firm Performance. (Doctor of Philosophy). The University of Utah.

Mak, Y. T. ve Kusnadi, Y. (2005) "Size Really Matters: Further Evidence on the Negative Relationship between Board Size and Firm Value" Pacific-Basin Finance Journal, 13: 301- 318.

Masulis, R. W., Wang, C. ve Xie, F. (2012) "Globalizing The Boardroom-The Effects of Foreign Directors on Corporate Governance and Firm Performance" Journal of Accounting and Economics, 53: 527- 554.

Mura, R. (2007) "Do Non-Executive Directors and Institutional Investors Have Minds of Their Own? Evidence on Performance of UK Firms" http://www. efmaefm.org/efma2005/papers/179-mura_paper.pdf (02.03.2014).

Mollah S., Al Farooque O. ve Karim W. (2012) "Ownership Structure, Corporate Governance and Firm Performance Evidence from an African Emerging Market" Studies in Economics and Finance, 29(4): 301319.

Moscu, R. G. (2013) "The Relationship between Firm Performance and Bord Characteristics in Romania" International Journal of Academic Research in Economics and Management Sciences, 2(1): 167- 175.

Newey, W. K. ve West, K. D. (1987) "A Simple, Positive Semi-Definite, Heteroscedasticity and Autocorrelation Consistent Covariance Matrix" Econometrica, 55: 703708.

Newey, W. K. ve West, K. D. (1994) "Automatic Lag Selection in Covariance Matrix Estimation" Review of Economic Studies, 61: 631- 654.

Obradovich, J. D. ve Gill, A. (2013) "The Impact of Corporate Governance and Financial Leverage on the Value of American Firms" International Research Journal of Finance and Economics, 91: 1- 13.

Masulis, R. W., Wang, C. ve Xie, F. (2012) "Globalizing The Boardroom-The Effects of Foreign Directors on Corporate Governance and Firm Performance" Journal of Accounting and Economics, 53: 527- 554.

Ocak, M. (2013) "Yönetim Kurulu ve Üst Yönetimde Yer Alan Kadınların Finansal Performansa Etkisi:
Türkiyesye İlişkin Bulgular" Muhasebe ve Finansman Dergisi, 60: 107- 126.

Okka, O. (2009) "Analitik Finansal Yönetim Teori ve Uygulamalar" (1. Baskı). Ankara: Nobel Yayınevi.

Oxelheim, L. ve Randøy, T. (2003) "The Impact of Foreign Board Membership on Firm Value" Journal of Banking \& Finance, 27: 2369- 2392.

Parks, R. (1967) "Efficient Estimation of a System of Regression Equations When Disturbances Are Both Serially and Contemporaneously Correlated" Journal of the American Statistical Association, 62(318): 500509.

Peng, M. W., Zhang, S. ve Li, X. (2007) "CEO Duality and Firm Performance during China's Institutional Transitions" Management and Organization Review 3(2): 205- 225.

Phung, D. N. ve Hoang T. P. T. (2013) “Corporate Ownership and Firm Performance in Emerging Market: A Study of Vietnamese Listed Firms" Proceedings of World Business and Social Science Research Conference 24-25 October, 2013, Novotel Bangkok on Siam Square, Bangkok, Thailand, ISBN: 978-1-922069-33-7.

Postma, T. J. B. M., Ees H. V. ve Sterken, E. (2003) "Board Composition and Firm Performance in the Netherlands" Eastern Economic Journal, 29: 41- 58.

Rad F. H., Rajeh K. Z. S., Botyari E. ve Bezminabadi G. N. (2013) "The Impact of Corporate Governance on Firm's Financial Performance: A Comparison between Iranian and Malaysian Listed Companies" Life Science Journal, 10(6s): 49- 55.

Randøy, T., Thomsen, S. ve Oxelheim, L. (2006) "A Nordic Perspective on Corporate Board Diversity" Nordic Innovation Centre, 1- 32, http://www. nordicinnovation.org/Global/_Publications/ Reports/2006/The\%20performance\%20effects\%20 of\%20board\%20diversity\%20in\%20Nordic\%20Firms. pdf (01.01.2014).

Rashid A., Zoysa A. D., Lodh S. ve Rudkin K. (2010) "Board Composition and Firm Performance: Evidence from Bangladesh" Australasian Accounting Business and Finance Journal, 4(1): 76- 95.

Rehman, A. ve Shah S. Z. A. (2013) "Board Independence, Ownership Structure and Firm Performance: Evidence from Pakistan"Interdisciplinary Journal of Contemporary Research In Business, 5(3): 832- 845 .

Rose, C. (2007) "Does Female Board Representation Influence Firm Performance? The Danish Evidence" Journal of Corporate Governance: An International Review, 15: 404-413. 
Saliha, T. \& Abdessatar A. (2011). The Determinants of Financial Performance: An Empirical Test Using the Simultaneous Equations Method. Economics and Finance Review, 10(1), 01 - 19.

Saravanan, P. (2012) "Corporate Governance and Company Performance- A Study With Reference to Manufacturing Firms in India" http://www.nfcgindia. org/pdf/cor_gover_manu_firms.pdf (10.12.2013).

Schwizer, P., Soana M-G. ve Cucinelli, D. (2013) "The Relationship between Board Diversity and Firm Performance: The Italian Evidence" http://www. adeimf.it/new/images/stories/Convegni/Novara/ Soana_Schwizer_Cucinelli_Board_diversity.pdf (11.02.2014).

Shukeri, S. N., Shin, O. W. ve Shaari, M. S. (2012) "Does Board of Director's Characteristics Affect Firm Performance? Evidence From Malaysian Public Listed Companies" International Business Research, 5(9): 120127.

Sueyoshi T., Goto M. ve Omi Y. (2010) "Corporate Governance and Firm Performance: Evidence from Japanese Manufacturing Industries after the Lost Decade" European Journal of Operational Research, 203: 724-736.

Swastika, D. L. T. (2013). Corporate Governance, Firm Size, and Earning Management: Evidence in Indonesia Stock Exchange. IOSR Journal of Business and Management (IOSR-JBM), e-ISSN: 2278-487X, p-ISSN: 2319-7668, 10(4), 77-82.

Taghizadeh, M. ve Saremi S. Y. (2013) "Board of Directors and Firms Performance: Evidence from Malaysian Public Listed Firm" DOI: 10.7763/IPEDR. . 59. 37, 178- 182, http://www.ipedr.com/vol59/037ICEMM2013-P10030.pdf (03.07.2014).

Tatoğlu, F. Y. (2013) "ileri Panel Veri Analizi” (2.Baskı). İstanbul: Beta Yayınevi.

Ujunwa, A. (2012) "Board Characteristics and the Financial Performance of Nigerian Quoted Firms" Corporate Governance, 12(5): 1- 30.
Vafeas, N. ve Theodorou, E. (1998) "The Relationship between Board Structure and Firm Performance in the UK" British Accounting Review, 30: 383- 407.

Vo, D. ve Phan, T. (2013) "Corporate Governance and Firm Performance: Empirical Evidence From Vietnam" http://www.murdoch.edu.au/Schoolof-Management-and-Governance/_document/ Australian-Conference-of-Economists/Corporategovernance-and-firm-performance.pdf (03.12.2013).

Wang, Y. ve Clift, B. (2009) "Is There a "Business Case" for Board Diversity?" Pacific Accounting Review, 21(2): 88-103.

Wellalage, N. H. ve Locke, S. (2012) "Ownership Structure and Firm Financial Performance: Evidence from Panel Data in Sri Lanka" Journal of Business Systems, Governance \& Ethics, 7(1): 52- 65.

White, H. (1980) "A Heteroscedasticity-Consistent Covariance Matrix Estimator and a Direct Test for Heteroscedasticity" Econometrica, 48, 817- 838.

Wooldridge, J. M. (2002) "Econometric Analysis of Cross Section and Panel Data" Cambridge: MIT Press.

Yermack, D. (1996) "Higher Market Valuation of Companies with a Small Board of Directors" Journal of Financial Economics, 40: 185- 221.

Younas, Z.I., Mahmood, H. ve Saeed, A. (2013)“Effect of Firm Performance on Corporate Governance a Panel Data Analysis" Asian Journal of Empirical Research, 3(1): 1- 8 .

Yu, M. (2008) "CEO Duality and Firm Performance for Chinese Shareholding Companies" 19th Chinese Economic Association (UK) Annual Conference, http:// www.ceauk.org.uk/2008-conference-papers/ YU-mei-CEO-duality-firm-performance-Chineseshareholding-companies.pdf (07.01.2014).

Zeitun, R. ve Tian, G. G. (2007) “Does Ownership Affect a Firm's Performance and Default Risk in Jordan?" Corporate Governance: The International Journal of Business in Society, 7 (1): 66- 82. 


\section{EKLER}

EK 1: Panel Birim Kök Testi Sonuçları

\begin{tabular}{|c|c|c|c|c|}
\hline \multirow{2}{*}{ DEǦişKENLER } & \multicolumn{2}{|c|}{ LLC Testi } & \multicolumn{2}{c|}{ PP Fisher Testi } \\
\cline { 2 - 5 } & T-testi & Olasılık (p) & İstatistik & Olasılık (p) \\
\hline TOBIN & $-5,270$ & 0,0002 & 34,0356 & 0,0012 \\
\hline ROA & $-52,380$ & 0,0000 & 112,3750 & 0,0000 \\
\hline ROE & $-62,652$ & 0,0000 & 119,5242 & 0,0000 \\
\hline ALTMAN & $-3,654$ & 0,0005 & 32,5423 & 0,0017 \\
\hline YABPAYI & $-4,325$ & 0,0021 & 33,5952 & 0,0015 \\
\hline KALDIRAC & $-6,562$ & 0,0003 & 37,2512 & 0,0010 \\
\hline VARLIK & $-8,650$ & 0,0042 & 40,2320 & 0,0002 \\
\hline YAS & $-18,350$ & 0,0021 & 55,9850 & 0,0000 \\
\hline
\end{tabular}

EK 2: Hausman Testi

\begin{tabular}{|c|c|c|}
\hline Modeller & Chi $^{\mathbf{2}}$ testi & Olasılık (p) \\
\hline Model 1 & 45,0542 & 0,0000 \\
\hline Model 2 & 36,0215 & 0,0000 \\
\hline Model 3 & 41,2151 & 0,0000 \\
\hline Model 4 & 48,0874 & 0,0000 \\
\hline
\end{tabular}

EK 3: Otokorelasyon Testi Sonuçları

\begin{tabular}{|c|c|c|}
\hline Modeller & $\begin{array}{c}\text { Bhargava, Franzini ve } \\
\text { Narendranathan'ın Durbin } \\
\text { Watson testi }\end{array}$ & $\begin{array}{c}\text { Baltagi-Wu'nun Yerel En Iyi } \\
\text { Değişmez Testi (LBI) }\end{array}$ \\
\hline Model 1 & 1,43 & 1,66 \\
\hline Model 2 & 1,53 & 1,63 \\
\hline Model 3 & 1,55 & 1,69 \\
\hline Model 4 & 1,34 & 1,45 \\
\hline
\end{tabular}

EK 4: Birimler Arası Korelasyon Testleri Sonuçları

\begin{tabular}{|c|c|c|}
\hline \multirow{2}{*}{ Modeller } & \multicolumn{2}{|c|}{ Pesaran'ın Testi } \\
\cline { 2 - 3 } & Değer & Olasılık (p) \\
\hline Model 1 & 18.325 & 0,0000 \\
\hline Model 2 & 11.805 & 0,0000 \\
\hline Model 3 & 22.650 & 0,0000 \\
\hline Model 4 & 35.252 & 0,0000 \\
\hline
\end{tabular}


EK 5: Çoklu Varyans (Heteroskedasite) Testi Sonuçları

\begin{tabular}{|c|c|c|}
\hline \multirow{2}{*}{ Modeller } & \multicolumn{2}{|c|}{ Değiştirilmiş Wald Testi } \\
\cline { 2 - 3 } & Chi2 & Olasılık (p) \\
\hline Model 1 & 5807.25 & 0,000 \\
\hline Model 2 & 3250.50 & 0,000 \\
\hline Model 3 & 4536.50 & 0,000 \\
\hline Model 4 & 3985,25 & 0,000 \\
\hline
\end{tabular}

